Article

\title{
Geomorphological Changes of a Migrating Sandbank: Multidecadal Analysis as a Tool for Managing Conflicts in Coastal Use
}

\author{
Annelore Bezzi ${ }^{1, *(\mathbb{D})}$, Giulia Casagrande ${ }^{1}$, Saverio Fracaros ${ }^{1}\left(\mathbb{D}\right.$, Davide Martinucci ${ }^{1}$, Simone Pillon ${ }^{1}$ (D), \\ Stefano Sponza ${ }^{1}$, Antonio Bratus ${ }^{2}$, Fabrizio Fattor ${ }^{2}$ and Giorgio Fontolan $1,3, * \mathbb{D}$
}

check for

updates

Citation: Bezzi, A.; Casagrande, G.; Fracaros, S.; Martinucci, D.; Pillon, S.; Sponza, S.; Bratus, A.; Fattor, F.; Fontolan, G. Geomorphological Changes of a Migrating Sandbank: Multidecadal Analysis as a Tool for Managing Conflicts in Coastal Use. Water 2021, 13, 3416. https:// doi.org/10.3390/w13233416

Academic Editor:

Miguel Ortega-Sánchez

Received: 26 October 2021

Accepted: 30 November 2021

Published: 3 December 2021

Publisher's Note: MDPI stays neutral with regard to jurisdictional claims in published maps and institutional affiliations.

Copyright: (c) 2021 by the authors Licensee MDPI, Basel, Switzerland. This article is an open access article distributed under the terms and conditions of the Creative Commons Attribution (CC BY) license (https:// creativecommons.org/licenses/by/ $4.0 /)$.
1 Department of Mathematics and Geosciences, University of Trieste, Via E. Weiss 1, 34128 Trieste, Italy; gcasagrande@units.it (G.C.); saverio.fracaros@phd.units.it (S.F.); dmartinucci@units.it (D.M.); spillon@units.it (S.P.); sponza@units.it (S.S.)

2 Autonomous Region of Friuli Venezia Giulia, Geological Survey, Via S. Anastasio 3, 34132 Trieste, Italy; antonio.bratus@regione.fvg.it (A.B.); fabrizio.fattor@regione.fvg.it (F.F.)

3 National Interuniversity Consortium for Marine Sciences, CoNISMa, Piazzale Flaminio 9, 00196 Rome, Italy

* Correspondence: bezzi@units.it (A.B.); fontolan@units.it (G.F.)

\begin{abstract}
While beach erosion and sand loss are typically of great concern to the tourism industry, managing rapid morphological changes linked to large amounts of moving sediments is the challenge facing Grado, an important seaside resort in the northern Adriatic, Italy. The cause of the unusual management conflict is the presence of the Mula di Muggia Bank, a nearshore depositional system made up of relict and active migrating sandbanks extending up to $2 \mathrm{~km}$ seawards from the touristic beachfront. A reconstruction of the morpho-sedimentary evolution of the coastal system over a 200-year period was done using a large dataset which includes historical cartography, topographic maps, aerial photos and topo-bathymetric surveys. The results show the growth of a significant urban development aimed at creating a tourist destination by occupying the waterfront along fetchlimited coastal tracts with very shallow water and scarce hydrodynamics. Furthermore, a number of sandy dynamic landforms (longshore migrating bars, a bypass corridor, an ebb-tidal delta) and accumulation zones attest to a sediment excess which can be mostly attributed to the eastern river supplies. The progressive constant migration rate of $12.6 \mathrm{my}^{-1}$ allowed the bank to induce the expansion of the low-energy silty backbarrier environment, characterised by abundant seagrass meadows a short distance directly in front of the tourist beaches of Grado. As a result of historical analysis and more current observations, areas with diverse morphosedimentary features and with varying tourist/recreational, ecological, and conservation values have been identified. These can be considered as basic units for future accurate planning and re-evaluation of coastal management choices to balance environmental protection and tourist use. A soft coastal defence approach is proposed which includes either the preservation of specific environments or the proper use of excess sand for beach nourishment via periodic dredging or sediment bypassing.
\end{abstract}

Keywords: sandbank; migration; barrier; backbarrier; shoreline analysis; historical evolution; coastal zone management

\section{Introduction}

Coastal systems are the most densely populated locations on the planet, as well as the most vulnerable to sea-level rise (SLR) caused by global warming. Continued accelerated global SLR, along with potential increases in the frequency and intensity of extreme sea-level events [1,2], will cause rapid coastal changes in many parts of the world. Even currently, erosion, drowning and increased vulnerability involve sedimentary bodies such as beaches, coastal dunes, barrier island systems and deltas. The transgressive trend is exacerbated by the simultaneous severe anthropogenic influence on sediment supply and 
transport, as well as on coastal dynamics and subsidence [3-13]. In light of the environmental, socioeconomic, and cultural values of coastal areas, the coastal response and adaptation capability to relative SLR are not uniform and assume considerable local variation, making comprehension and prediction one of the most important and debated topics in scientific literature, i.e., [14,15]. The definition of the temporal scale is critical for assessing coastal evolution and distinguishing coastal change caused by episodic, seasonal, or longterm processes [16,17]. A multidecadal analysis of the shoreline is a basic requirement for coastal management and one of the classic geomorphological methodologies [18-23]. Shoreline analysis is typically performed using historical databases, aerial photos, and maps, which are then supplemented with GPS surveys and high-resolution remote sensing methodologies $[17,19-21]$. Long-term series are not always available due to the lack of historical institutional databases for coastal monitoring, such as those in the United States [19,24], Belgium [25], or the Netherlands [26]. At the same time, the integration of heterogeneous databases poses problems due to differing levels of accuracy and precision of survey measurements and is heavily dependent on the correct choice of a shoreline proxy indicator [27].

Even more complex is the issue that arises when dealing with bathymetric data, which typically represents the basis for a more complete morphological analysis and sedimentbudget approach [22,28-34]. The qualitative-quantitative analysis of historical and recent data should also include a more thorough examination of the morphological elements and their evolution $[18,35,36]$ completed by the analysis of territorial development $[23,36,37]$, which will allow both to have a pertinent geomorphological framework and assess the anthropogenic influence on coastal evolution.

In this work we analyse the Mula di Muggia Bank (hereinafter MMB), a nearshore depositional system made up of active and relict sandbanks that extends up to $2 \mathrm{~km}$ seawards from the touristic beachfront of Grado (northern Adriatic, Italy). While erosion and sand loss are always key issues for the tourism business [38-43], managing rapid morphological changes linked to large quantities of moving sediments is the challenge here. The reconstruction of the morphological evolution over a 200-year period, combined with an overview of the most significant anthropogenic changes, addresses the need to develop an adequate knowledge base for effective future planning and re-evaluation of coastal management decisions to balance environmental protection and tourist use.

\section{Study Area}

\subsection{Geographic Setting}

The study area, entirely included in the Municipality of Grado, is located between the Grado inlet and the mouth of the Isonzo River, in the Gulf of Trieste, northern Adriatic, Italy (Figure 1). It represents the easternmost part of the system of barrier islands bordering the Grado Lagoon and is nearly entirely devoted to tourism and agriculture. Grado is a tourist town with approximately 8000 inhabitants, which more than triples during the summer season; the number of nights spent in tourist accommodation is ca. 1.4 million per year [44].

Seaward, a wide system of intertidal and subtidal sand bars extends until a depth of $3 \mathrm{~m}$. Their morphology was first mapped and described by [45] and, more recently, by [46-49]. From the planimetric view, the belt of multiple sandy bars forms two arcuate triangular shapes (the MMB and the delta complex of the Isonzo River), which extend up to $2 \mathrm{~km}$ seawards, and converge towards a landward central point, ideally represented by the tidal inlet of Primero. Overall, these morphological systems represent an anomaly in the regular bathymetric trend of the northern Adriatic and the Gulf of Trieste, with a strong extroflection of the nearshore contour lines, corresponding to high sediment thicknesses (up to $8 \mathrm{~m}$ ) deposited during the Holocene, following the Last Glacial Maximum [50]. 


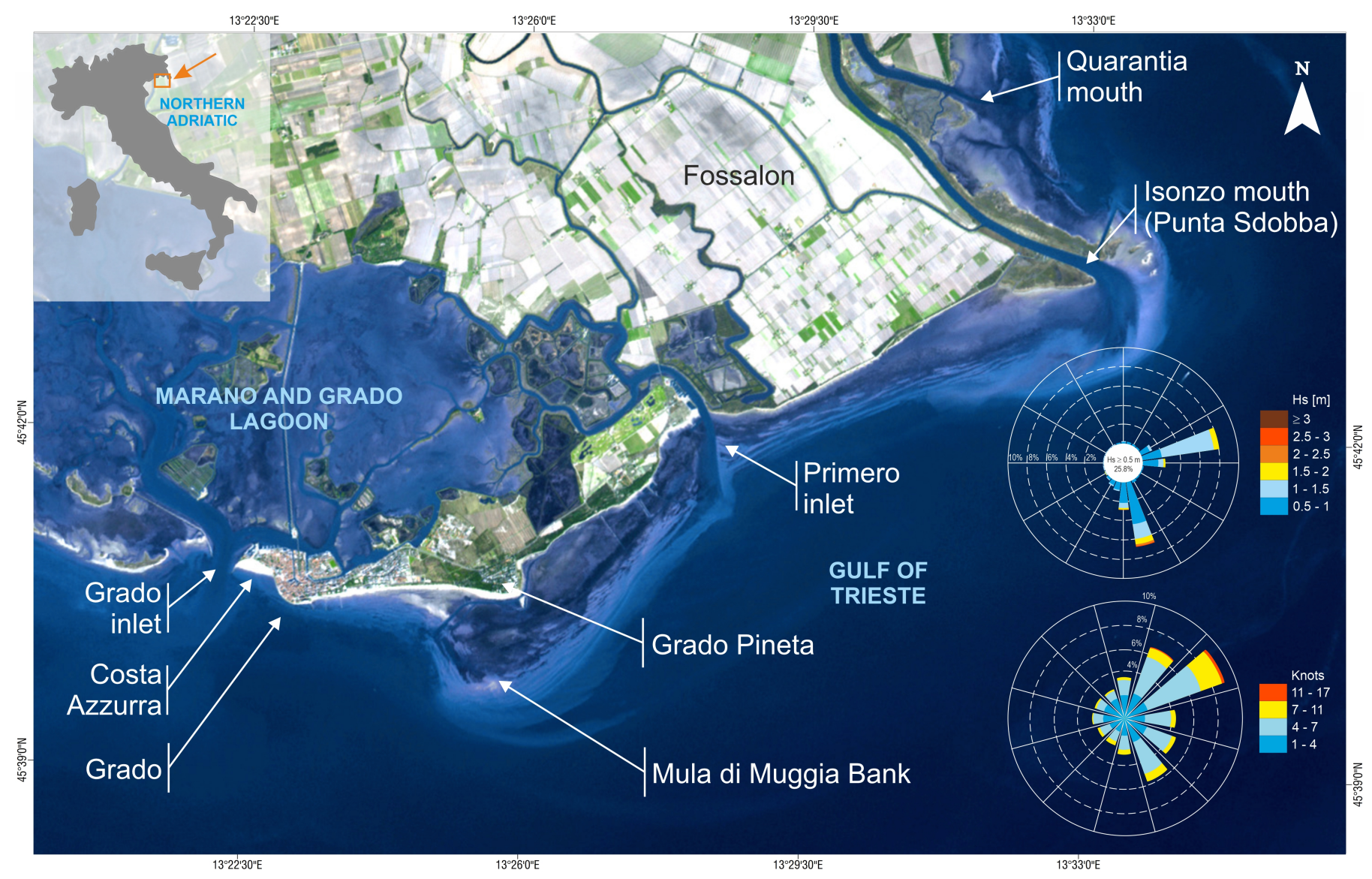

Figure 1. Overview of the study area (Basemap: Landsat, in false-colour, wind and wave roses redrawn from [51]).

A large part of the $\mathrm{MMB}$, as well as the mouth of the Isonzo River, are currently part of the Natura 2000 network (Special Areas of Conservation and Special Protection Area IT 3330006 and IT 3330005). The Autonomous Region of Friuli-Venezia Giulia has added both sites to its list of regional geosites.

The Isonzo River is the principal sediment source in the area. The drainage basin of the Isonzo has a total extension of $3452 \mathrm{~km}^{2}$, with major tributaries (the Natisone-Torre and Vipacco Rivers). The average annual flow rate at the river mouth is $196.8 \mathrm{~m}^{3} \mathrm{~s}^{-1}$, ranging monthly from 43.1 to $665.9 \mathrm{~m}^{3} \mathrm{~s}^{-1}$ [52]. The 18-19 November 1940 flood reached $4400 \mathrm{~m}^{3} \mathrm{~s}^{-1}$, flooding 350 hectares of crops on Isola Morosini, not far from the river mouth [53]. Despite the lack of data, the torrential regime of the river, which collects and discharges the waters from the southern slope of the Julian Alps, and the extremely high rainfall of its Prealps catchment (mean yearly rainfall between 2700 and $3200 \mathrm{~mm}$ ) support the hypothesis of the significant potentiality of solid river discharge. Instead, extensive anthropogenic modification (afforestation, river damming, and river-bed sand mining) has been blamed for a significant decrease in fluvial sediment load over the last century, according to some authors [54,55]. The decline is not directly measured but is confirmed by the evidence of morphological changes to the river bed [55].

\subsection{Oceanographic and Meteoclimatic Forcing}

The wind climate of the northern Adriatic is characterised by the predominance of winds from the first quadrant, primarily from the ENE direction (the Bora) either in terms of frequency or strength $[51,56]$. South-easterly winds (the Scirocco) with a longer geographic fetch (more than $800 \mathrm{~km}$ ) are also significant. Tides in the Gulf of Trieste are semi-diurnal with a mean range of $76 \mathrm{~cm}$ [57], a mean spring-tide range of $105 \mathrm{~cm}$, and a mean neap tide of $22 \mathrm{~cm}$ [58]. The combination of spring tides, seiches, south-easterly winds, and low atmospheric pressure can result in an exceptional rise in sea level (known as "acqua alta"), 
which reached $194 \mathrm{~cm}$ over the Venice benchmark on 4 November 1966. Due to the Bora and the Scirocco winds, the wave regime is typically bimodal. According to data recorded at the wave buoy OGS-DWRG1 (located at the coordinates $13.24^{\circ} \mathrm{E}, 45.56^{\circ} \mathrm{N},-16 \mathrm{~m}$ depth), the mean significant wave height $\left(\mathrm{H}_{\mathrm{s}}\right)$ is less than $0.5 \mathrm{~m}$. Events with $\mathrm{H}_{\mathrm{s}}$ greater than $0.5 \mathrm{~m}$ account for $25 \%$ of the overall record, with prevailing waves from the SE $(10.7 \%)$ and ENE $(10.5 \%)$. The Scirocco has the highest recorded waves, with $\mathrm{H}_{\mathrm{s}}=4.4 \mathrm{~m}$ [51]. The yearly wave energy for the northern Adriatic area is $15.61 \mathrm{~m}^{2} \mathrm{~s}^{2}$ [59]. Forced by the prevailing Bora winds, short waves act along the coastal area of Grado inducing a longshore drift directed westward from the Isonzo River to Grado.

\section{Materials and Methods}

To conduct this study, a large dataset was collected, analysed and critically selected, including data of various origins. Historical cartography (from 1798 to 1830), topographic maps (from 1869 to 2003), aerial photos (from 1954 to 2019) and nautical map ((1927) or topo-bathymetric surveys (from 1968 to 2019) were used to recognize the landforms, identify anthropogenic changes, and interpret the morpho-sedimentary processes. A part of the collected data was used to map the landform changes over time, to identify some geomorphological indicators and to support the quali-quantitative analysis.

According to the quality and reliability of the sources, we followed two different approaches. The first approach involved historical cartography: earlier depictions of the area were frequently inaccurate, and in some cases completely fictitious. After careful comparison between them, the chosen maps had to represent plausible morphological elements that were recognisable over time. The second approach concerned the correlation of recent data. The availability of different types of information over a long period of time raises the question of how the data should be associated. For this reason, the available materials we chose had to be relative to the same year (for example, aerial photos and topo-bathymetric surveys from 2007), or could be comparable in a very limited time span (for example, aerial photos from 1978 and topo-bathymetric surveys from 1985), or were of the same type (for example, photointerpretation data).

To evaluate the morphological changes of the MMB, a topo-bathymetric survey was carried out in 2019. A double sampling approach was chosen: we replicated the profiles placed at the same points in 1968 to have the best-matched data possible, while for the most dynamic areas such as bars, troughs, and channels, a higher density acquisition was performed for better reconstruction. All the specific information about the survey methodology and detailed results are reported in [60]. Table 1 summarises the entire dataset, including the cartographic databases consulted on the internet [61,62]. 
Table 1. Summary of the entire dataset used for elaboration. A, B, C, D refer to the use of the data or the type of results obtained: (A) basemap, also consulted for information on anthropogenic changes; (B) consulted for the morphological and sedimentological interpretation; (C) cartographic restitution of the interpreted morphologies and sedimentology; (D) reference period of the multidecadal evolution (see Section 4.2).

\begin{tabular}{|c|c|c|c|c|c|c|}
\hline \multirow{2}{*}{ Survey Year } & \multirow{2}{*}{ Type of Source Data } & \multirow{2}{*}{ References } & \multicolumn{4}{|c|}{ Type of Resulting Data } \\
\hline & & & A & B & $\mathrm{C}$ & $\mathbf{D}$ \\
\hline $1798-1805$ & historical map & Kriegskarte von Zach & & $\bullet$ & & \\
\hline $1822-1824$ & historical map & $\begin{array}{l}\text { Carta di cabotaggio del mare Adriatico, Istituto Geografico Militare } \\
\text { di Milano }\end{array}$ & $\bullet$ & & $\bullet$ & $\mathrm{I}$ \\
\hline 1830 & historical map & Franziszeische Landesaufnahme [61] & $\bullet$ & & $\bullet$ & I \\
\hline 1869-1887 & topographic map & Franzisco-Josephinische Landesaufnahme [61] & & $\bullet$ & & II \\
\hline 1894 & topographic map & Topographische Karte, Militärgeographisches Institut & $\bullet$ & & $\bullet$ & II \\
\hline 1915-1917 & topographic map & $\begin{array}{c}\text { Grado, F. 40II.S.E. della Carta d'Italia, Istituto Geografico } \\
\text { Militare, } 1917 \\
\text { Punta Sdobba, F. 40III.S.O. della Carta d'Italia, Istituto Geografico } \\
\text { Militare, } 1915\end{array}$ & & $\bullet$ & & III \\
\hline 1927 & nautical map & $\begin{array}{l}\text { Marina di Grado, Istituto Idrografico della Marina, } 1928 \\
\text { (survey 1927) }\end{array}$ & & & $\bullet$ & III \\
\hline 1938 & topographic map & $\begin{array}{c}\text { Grado, F. 40II.S.E. della Carta d'Italia, Istituto Geografico Militare } \\
\text { Punta Sdobba, F. 40III.S.O. della Carta d'Italia, Istituto } \\
\text { Geografico Militare }\end{array}$ & $\bullet$ & & $\bullet$ & III \\
\hline 1949 & topographic map & $\begin{array}{c}\text { Grado, F. 40II.S.E. della Carta d'Italia, Istituto Geografico Militare } \\
\text { Foce dell'Isonzo, F. 40III.S.O. della Carta d'Italia, Istituto } \\
\text { Geografico Militare }\end{array}$ & $\bullet$ & $\bullet$ & & IV \\
\hline 1954 & aerial photos & GAI (Gruppo Aereo Italiano) & & & $\bullet$ & IV \\
\hline 1959 & topographic map & $\begin{array}{l}\text { Foce dell'Isonzo, F. 40III.S.O. della Carta d'Italia, Istituto } \\
\text { Geografico Militare }\end{array}$ & $\bullet$ & $\bullet$ & & $\mathrm{V}$ \\
\hline 1968 & $\begin{array}{l}\text { topo-bathymetric } \\
\text { survey }\end{array}$ & $\begin{array}{c}\text { Consiglio Nazionale delle Ricerche (CNR) Project "Studio del } \\
\text { regime dei litorali" }\end{array}$ & & & $\bullet$ & $\mathrm{V}$ \\
\hline 1972-1973 & sedimentological survey & $\begin{array}{c}\text { Consiglio Nazionale delle Ricerche (CNR) } \\
\text { Project "Regime e Conservazione dei litorali italiani", 1970-1975 [54] }\end{array}$ & & $\bullet$ & & $\mathrm{V}$ \\
\hline 1974 & topographic map & $\begin{array}{c}\text { Carta Tecnica Regionale (CTR)_Regione Autonoma Friuli } \\
\text { Venezia Giulia, } \\
\text { flight 1974, published in } 1978\end{array}$ & $\bullet$ & $\bullet$ & & $\mathrm{V}$ \\
\hline 1978 & aerial photos & $\begin{array}{l}\text { Consiglio Nazionale delle Ricerche (CNR)_Project "Dinamica dei } \\
\text { litorali", 1975-1980 }\end{array}$ & & & $\bullet$ & $\mathrm{V}$ \\
\hline 1985 & $\begin{array}{l}\text { topo-bathymetric } \\
\text { survey }\end{array}$ & Regione Autonoma Friuli Venezia Giulia, 1985 [54] & & & $\bullet$ & VI \\
\hline 1985 & sedimentological survey & Regione Autonoma Friuli Venezia Giulia, 1985 [54] & & & $\bullet$ & VI \\
\hline 1990 & topographic map & $\begin{array}{c}\text { Carta Tecnica Numerica Regionale (CTNR)-Regione Autonoma } \\
\text { Friuli Venezia Giulia, flight 1990, published in } 1993\end{array}$ & $\bullet$ & $\bullet$ & & VI \\
\hline 2003 & topographic map & $\begin{array}{l}\text { Carta Tecnica Numerica Regionale (CTNR)—Regione Autonoma } \\
\text { Friuli Venezia Giulia_-aggiornamento generale anno } 2003\end{array}$ & $\bullet$ & $\bullet$ & & VI \\
\hline 2007 & digital orthophoto & Available on Geoportale Nazionale [62] & & & $\bullet$ & VI \\
\hline 2007 & $\begin{array}{l}\text { topo-bathymetric } \\
\text { survey }\end{array}$ & $\begin{array}{c}\text { MIUR FISR_-Project "Vector" (coordinated by } \\
\text { CoNISMa-Consorzio Nazionale Interuniversitario per le Scienze } \\
\text { del Mare), 2006-2009 }\end{array}$ & & & $\bullet$ & VI \\
\hline 2018 & digital ortophotos & $\begin{array}{l}\text { Lidar surveys-true orthophoto of the Regione Autonoma Friuli } \\
\text { Venezia Giulia, 2017-2020 }\end{array}$ & $\bullet$ & $\bullet$ & & VII \\
\hline 2019 & $\begin{array}{l}\text { topo-bathymetric } \\
\text { survey }\end{array}$ & $\begin{array}{l}\text { University of Trieste, Interreg Project Italy-Croatia "Change We } \\
\text { Care" [60] }\end{array}$ & & & $\bullet$ & VII \\
\hline 2019 & $\begin{array}{l}\text { digital orthophotos } \\
\text { (UAV survey) }\end{array}$ & $\begin{array}{c}\text { University of Trieste, Interreg Project Italy-Croatia "Change We } \\
\text { Care" [60] }\end{array}$ & & & $\bullet$ & VII \\
\hline
\end{tabular}




\section{Results}

\subsection{Morpho-Sedimentary Configuration}

Thanks to the most recent topo-bathymetric surveys (2019) and photo interpretation (2018), a detailed geomorphological map was created (Figure 2). The map depicts four distinct zones of environmental and morphological homogeneity: (a) the Grado sector ( $G$ sector), which consists of the coastal area facing Grado and is characterised by bathing areas and a medium-gradient seabed (between 0.3 and 0.9\%); (b) the Mula di Muggia shoal complex (MMB sector), which has a strongly asymmetric shape and can be identified by the $-5 \mathrm{~m}$ contour line, and is about $1810 \mathrm{~m}$ from the shoreline in the western sector to a maximum of $2705 \mathrm{~m}$ in the eastern sector. The bank's apex is defined by barely emerging bars $(0.57 \mathrm{~m})$, whereas another emerging bank can be found near the tourist beach; (c) the Primero Inlet area (PI sector), representing the Primero tidal inlet system, which is characterised by the main ebb channel separating the MMB from (d) the Isonzo Delta (ID sector), the river's deltaic complex. Beaches vary in width along the entire coast: the central portion of sectors $\mathrm{G}$ and MMB, as well as the entire sector ID, have no or narrow beaches (average value of about $14 \mathrm{~m}$ ), while the remnant areas have an average value of about $75 \mathrm{~m}$. Behind the beaches, in sector ID, there is a large reclamation agricultural area.

A low-energy silty backbarrier environment with abundant seagrass meadows and microbial mats front the tourism beaches of G, MMB, and the western edge of ID. The shallow seabed is affected by numerous little canals used by small boats, some swimming "pools" and a small marina.

A barrier-upper shoreface system confines the backbarrier system to the sea between 300 and $1300 \mathrm{~m}$ from the shoreline. This is shown by an intertidal sandbank and a barred shoreface which indicate the sandy masses currently being transported longshore to the southwest. (Figure 3). The barrier system includes the emerging bars of the apex of the MMB that partially obstruct the marina's access canal in front of the Grado Pineta promontory. The bathymetric surveys were used to estimate the outer limit of this very dynamic zone, corresponding to a mean depth value of $2.7 \mathrm{~m}$. A series of crests and throughs may be seen offshore, overstepping the limit of the bank in a relatively flat area that morphologically resembles a terrace (see section A-A1 in Figure 2). These forms can be identified in the MMB zone between $-4 \mathrm{~m}$ and $-6 \mathrm{~m}$ and have been recognised as finger bars [63-66] after both an aerial photo and topo-bathymetric examination. Other elongated sandy relict bodies of unknown origin (the external bars in Figure 2) lie within a depth of $9 \mathrm{~m}$, as also indicated by $[49,50,67]$.

The PI sector has a distinct main ebb channel and a marginal channel, as well as evidence of a sediment bypass corridor connecting the updrift and downdrift flanks, following the main longshore drift.

The easternmost sector is the active sedimentary lobe of the Isonzo delta, nourished by the sediment supplied by the river at Punta Sdobba. The topographic profile (section B-B1 in Figure 2) is represented by the flat depositional delta front and the concave featureless transition from the delta front to the prodelta. 


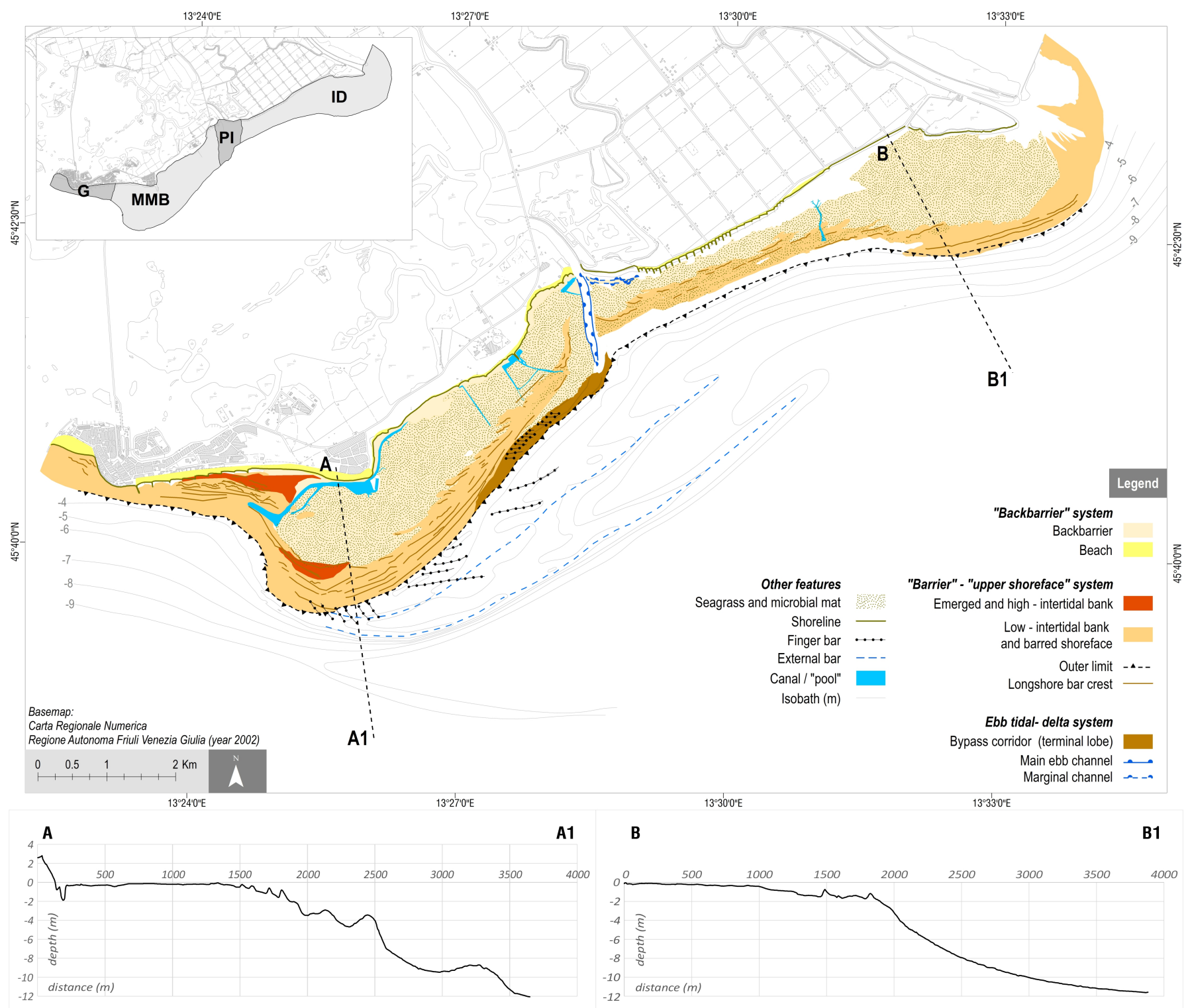

Figure 2. Geomorphological map of the coastal area including the Grado (G), Mula di Muggia (MMB), Primero inlet (PI) and Isonzo Delta (ID) sectors.

A sedimentological map, derived from the available sedimentological data, is proposed to complete the morpho-sedimentary frame (Figure 4; after [54]). The sedimentological evidence mirrors the morphological evidence and can be summarised as follows:

- Fine sand $(2<\mathrm{Mz}<3$ phi) is the most common sediment type of the beaches as a result of natural wave dynamics along this fetch-limited and protected shoreline.

- Very fine sand $(3<\mathrm{Mz}<4$ phi) occurs on the artificial beach between Grado and Grado Pineta, as well as on the barred shoreface in front of it, replaced by coarse silt from $-3 \mathrm{~m}$ seawards.

- An inversion of the normal coast-to-sea transition (seaward fining) occurs in the coastal tract, which is seaward limited by the sandbanks (MMB and ID). Here, the finest sediments ( $>3.5 \mathrm{phi}$, but mostly medium and fine silt) dominate the intertidal flat facing the shoreline, confirming the backbarrier characteristics of the area. Seaward, the sediments with the coarsest $\mathrm{Mz}(<2.5 \mathrm{phi})$ follow the bar and trough zone close to the outer limit of the bank and upper shoreface, identifying this zone as the most dynamic and exposed to wave action. Here the western longshore is active, and longshore elongated bars are the dominant landforms. 
- The seaward limit of the littoral sand prism can be identified between -5 and $-6 \mathrm{~m}$ in the ID zone, while on the seabed of the MMB a vast zone of pure, fine sand extends up to $-7 /-8 \mathrm{~m}$, corresponding to east-oriented sand bars, the origin of which is still unknown.

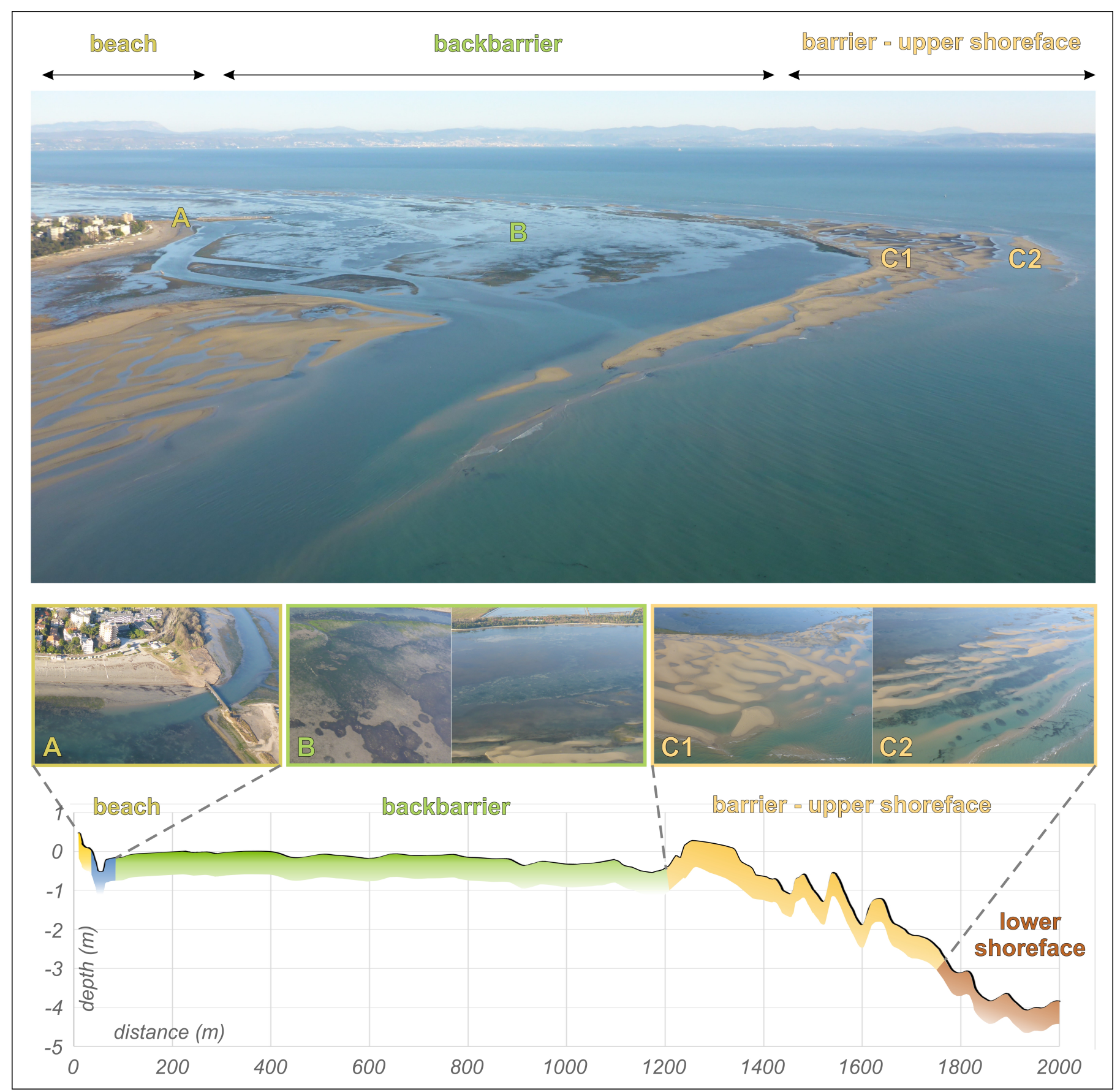

Figure 3. Morpho-bathymetric structure of the Mula di Muggia Bank. The barrier (C1) and the longshore bars (C2) migrate westward (from the top to the bottom of the upper image), thus obstructing the canal that crosses the backbarrier (B). The canal is the sole route for small boats to traverse the shallow silty zone toward the coastline (A) and the Grado Pineta marina. 


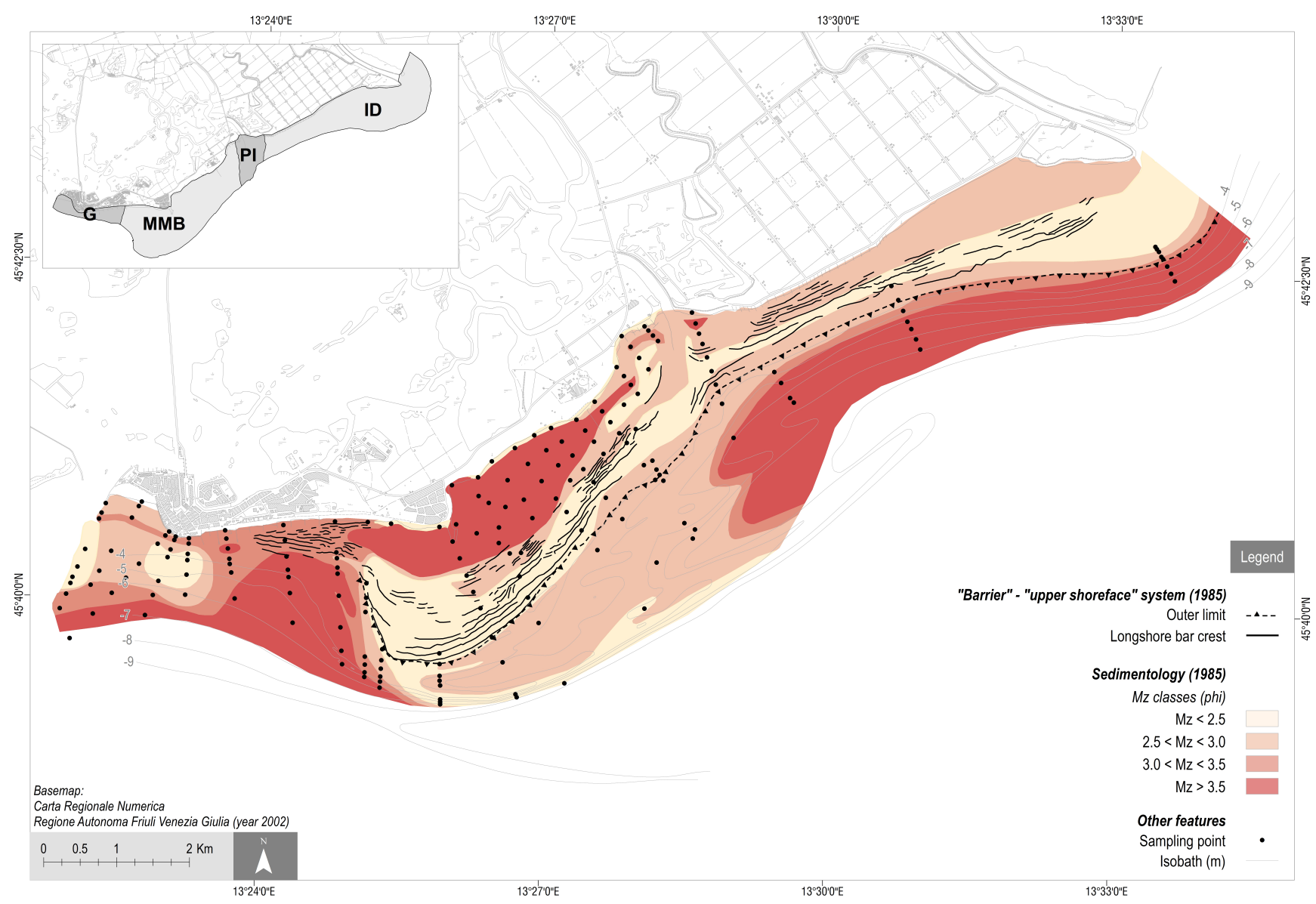

Figure 4. Sedimentological map (mean size, Mz in phi unit) of the beach and shoreface, depicting the longshore moving sand corridor $(\mathrm{Mz}<2.5 \mathrm{phi})$ from the Isonzo River to the Mula di Muggia Bank. Compiled after [54].

\subsection{Multi-Decadal Evolution}

The analysis of the historical cartography allows for the definition of the evolution of the coastal landforms between Grado and the mouth of the Isonzo River since 1800. It was possible to identify and describe the main characteristics of the MMB such as shape, specific elements, and position, as well as those of the Primero inlet and the Isonzo delta, using cartography available from 1822 to 1949 . The first aerial photos and topo-bathymetric surveys, however, did not arrive until 1954, providing greater precision to the identified forms and their evolution, both qualitatively and quantitatively.

According to the available data, the entire period was divided into seven-time intervals, and a summary of the most significant morphological changes and territorial transformations is presented below and in Figures 5 and 6.

\subsubsection{First Period (1822-1830)}

The first two historical maps are very similar in appearance with regard to the coastline which is mostly natural. Apart from Grado, which was portrayed as a small port settlement, the coast was undeveloped, consisting of a series of barrier islands separated by inlets (Porto di Grado, Rotta dei Moreri and Primero inlets) and characterised by well-developed coastal dunes. 


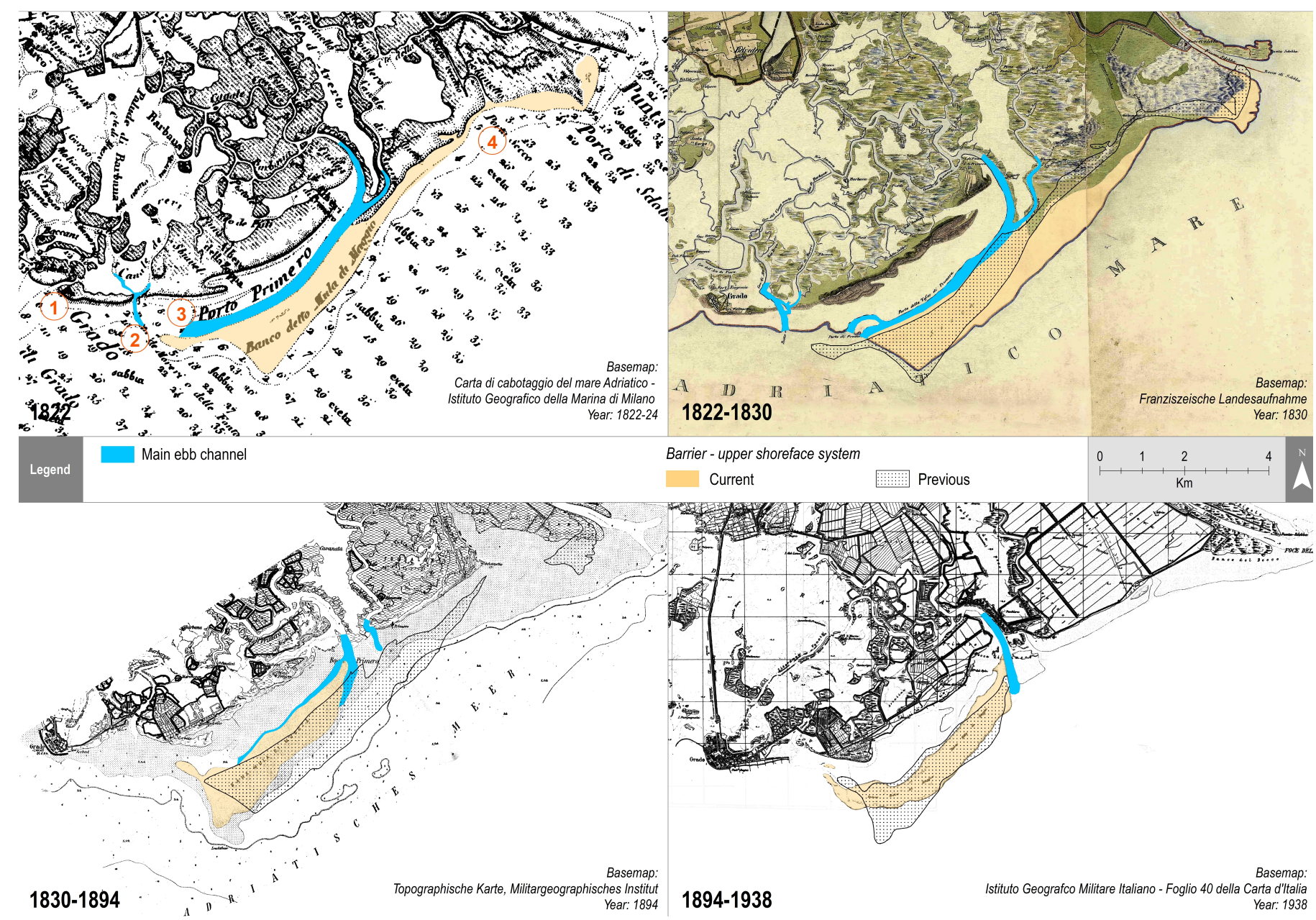

Figure 5. Evolution of the coastal tract in the period from 1822 to 1938, according to historical documents and maps. The main ebb channel of Primero and the barrier-upper shoreface system of the Mula di Muggia Bank are depicted for progressive comparison. Numbers in the oldest map refer to the following locations: 1-Porto di Grado, 2-Rotta dei Moreri, 3-Porto Primero, 4-Porto Secco, mouth of the Isonzo Vecchio.

The MMB was depicted as a northeast-southwest elongated sandy shoal in continuity with the eastern sand shoals extending up to the mouth of the Isonzo (Sdobba). Parallel to the coastline and seaward limited by the bank, the Primero channel (named Porto Primero) was lengthened by $5 \mathrm{~km}$ with a seaward decreasing depth from $5.8 \mathrm{~m}$ to $1.3 \mathrm{~m}$.

The morphological configuration of the area suggested a longshore transport from east to west, fed by the Isonzo River. The narrow channel of the old Isonzo (Isonzo Vecchio) that served as the river's main branch until the first half of the 1600s [68] is clearly evident between the Primero channel and the mouth of the Isonzo. The mouth of the Isonzo Vecchio is referred to as the Porto Secco in the oldest map.

\subsubsection{Second Period (1830-1894)}

Since 1830 a significant erosion phase of the coast has begun, affecting various sectors of the study area including the Grado beaches and the area around the Primero inlet. As a result of the retreating shoreline, a new breach of the Primero channel formed, leading directly into the sea in a north-south direction. Meanwhile, the MMB has migrated landward and westward. During this time, the coast began to be artificially stabilised by inlet closures (e.g., Rotta dei Moreri) and fish farm embankments in the Grado lagoon. The first beach resort in Grado is marked on the 1894 map. 


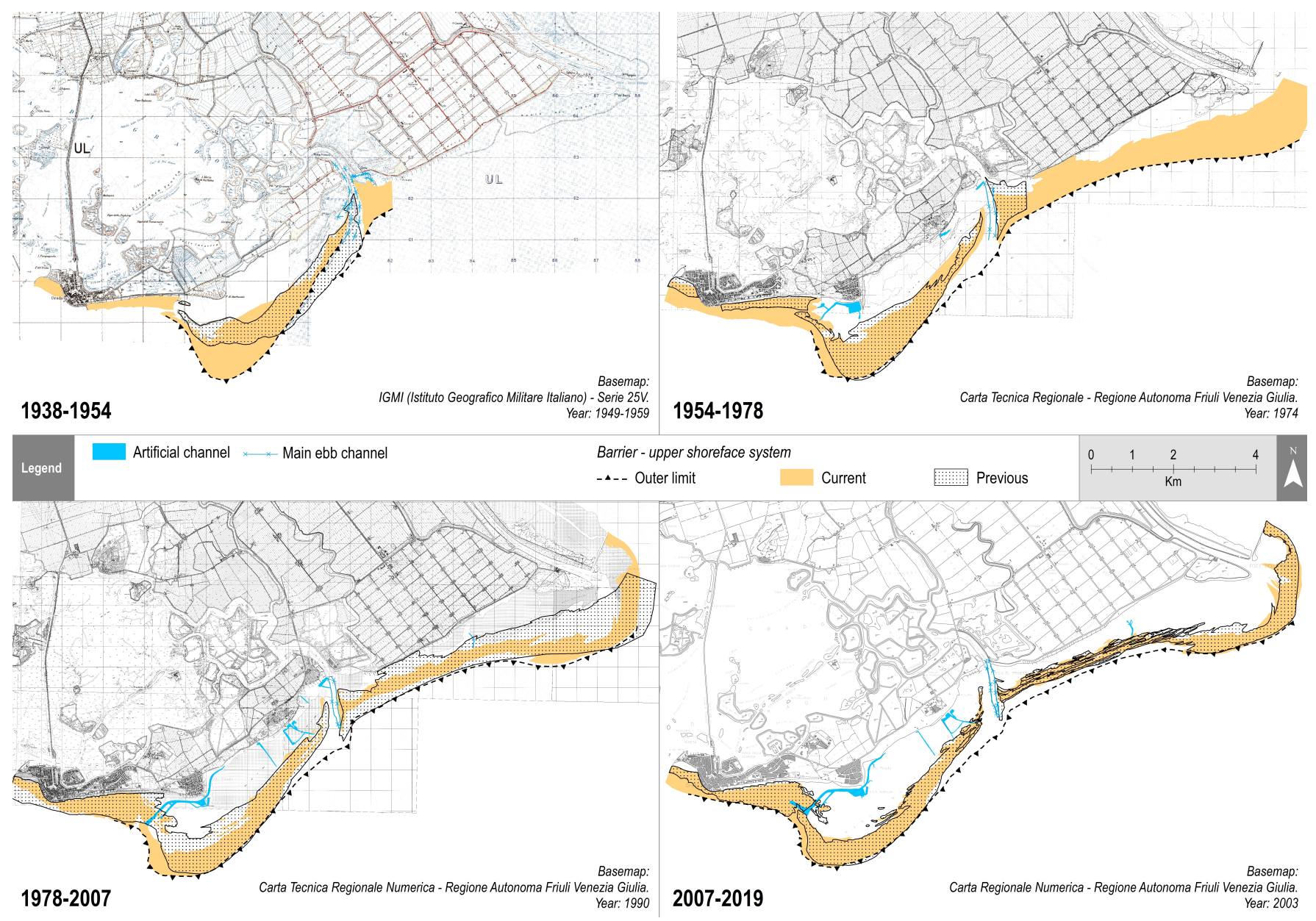

Figure 6. Evolution of the coastal tract in the period from 1838 to 2019, according to historical documents and maps. The main ebb channel of Primero, the canals and barrier-upper shoreface system of the Mula di Muggia Bank are depicted for progressive comparison.

\subsubsection{Third Period (1894-1938)}

The MMB continued to migrate landward and westward, apparently reducing its extent. However, we assumed that this modification is due to a different interpretation compared to the previous cartography, i.e., only the most emerged part of the bank has been mapped. The most notable coastal engineering works have been carried out since 1927 with the construction of the Bocca di Grado jetties (between 1927 and 1934) and the first phase of the tourist-seaside development of the city with the creation, from Grado toward the east of an artificial beach protected by groins. The necessary sand was extracted from coastal dunes on the barrier island between the current Grado Pineta and the mouth of Primero [45]. Concurrently, reclamation works on the lagoon lands behind the littoral up to Fossalon commenced with landfilling, mechanical drainage, and seaward embankments. According to the 1927 nautical map, the newly breached Primero channel became the main channel of the inlet, while the old one lost its hydraulic efficiency and began to silt up. Following a flood breach in 1896, a new mouth branch of the Isonzo (known as the Quarantia mouth) opened to the north [45], which grew in importance over time, quickly becoming the most important branch [68] until 1937, when it was artificially and definitively closed [45]. The 1927 nautical chart provides the first detailed bathymetry of the western side of the bank, allowing for the description of the submerged morphology of the area. 


\subsubsection{Fourth Period (1938-1954)}

Because of the interception of longshore sedimentary transport caused by the jetties built to stabilise the Grado inlet, a new beach developed in front of the historic centre of Grado, while the eastern beach was artificially completed with sand (around 90,000 $\mathrm{m}^{3}$ ) mined from the fronting sandy shoals. The first aerial photos (1954) and the first morphological analysis [45] enable us to observe in greater detail the MMB landforms by distinguishing the wide strip of active parallel sandy bars that migrate westward following the longshore transport. During this time, extensive reclamation between the Grado Pineta promontory and the mouth of the Isonzo was completed, with the direct result of reducing the extent of the Primero lagoon basin.

\subsubsection{Fifth Period (1954-1978)}

The availability of aerial photos (1978) and the 1968 topo-bathymetric survey allowed for a more accurate description of the MMB morphology, with evidence of a terrace-like bare flat with a series of sand bars on a seaward slope. During this time, the outer limit $(-2.7 \mathrm{~m})$ remained almost unchanged in the eastern sectors and at the apex of the bank, but the western sections continued to migrate westward. A low energy, silty backbarrier environment with large seagrass meadows may be seen behind the active barred area. Along the coast, urban and tourism development continued: the new coastal town of Grado Pineta was created, along with a groin, a small marina, little canals and a few "swimming pools" on the shallow seabed. The development of the latter resulted in a significant change in the hydraulic circulation of the backbarrier area.

\subsubsection{Sixth Period (1978-2007)}

The apex and eastern limit of the MMB remained almost unchanged, while the growth and migration of additional sand bars proceeded on the western margin. The topmost partially emerging bar assumed a nearly N-S direction, resulting in partial occlusion of the newly dug channel in front of the Grado Pineta promontory. This canal was constructed in the 1980s to improve water circulation in the backbarrier. Grado's eastern beach began to be directly influenced by the migration of the MMB with the extension of submerged sandbanks, which isolated $800 \mathrm{~m}$ of beach from wave action, favouring the sedimentation of fine sediments. At the Primero inlet, a clear ebb-tidal delta structure is recognisable, with evidence of a sediment bypass corridor connecting the updrift and downdrift flanks, following the main longshore drift. Seagrasses colonised vast stretches of the backbarrier, indicating a newly stabilised, low-energy environment. An increase in seagrass extension also occurred between the Primero inlet and the mouth of the Isonzo, occupying the calm runnels and troughs of the depositional multi-barred upper shoreface which is constantly nourished by the river sediments.

\subsubsection{Seventh Period (2007-2019)}

The Costa Azzurra beach accretion, which had mostly occurred throughout the fourth period, slowed during this time. The eastern boundary of the MMB, as well as the apical part, remained fairly unchanged but the sandbanks continued to spread to the west. The emergent bar from the previous time period expanded, moving to the northwest and isolating a new section of the tourist beach. Bars and troughs between Primero and the mouth of the Isonzo River were preserved, showing evidence of migration towards the west in the direction of the prevailing longshore currents.

\subsection{The Bank Migration}

According to the available historical and modern documentation, the MMB system has been preserved for more than a century, albeit with a significant migration to the west due to longshore drift.

Data from photointerpretation and historical cartography from 1830 to 2019, in particular, allowed us to recognize the bank's external limit planimetrically and detail the 
progressive migration westward of the sandy bars that form it (Figure 7). The limit of the bank was already mapped in the cartographic documents, while in aerial photographs it was recognisable by easily distinguished morphological elements such as sand bars or wave breaking lines (see Section 4.1). The numbered vectors in the map of Figure 7 depict the maximum shift of the western limit of the MMB between succeeding data, indicating a constant trend over time with a rate of around $12.6 \mathrm{my}^{-1}$. Landward, the progressive western migration and extension of the intertidal sandy bars take place in front of the beach, creating a progressively wider shallow nearshore zone.

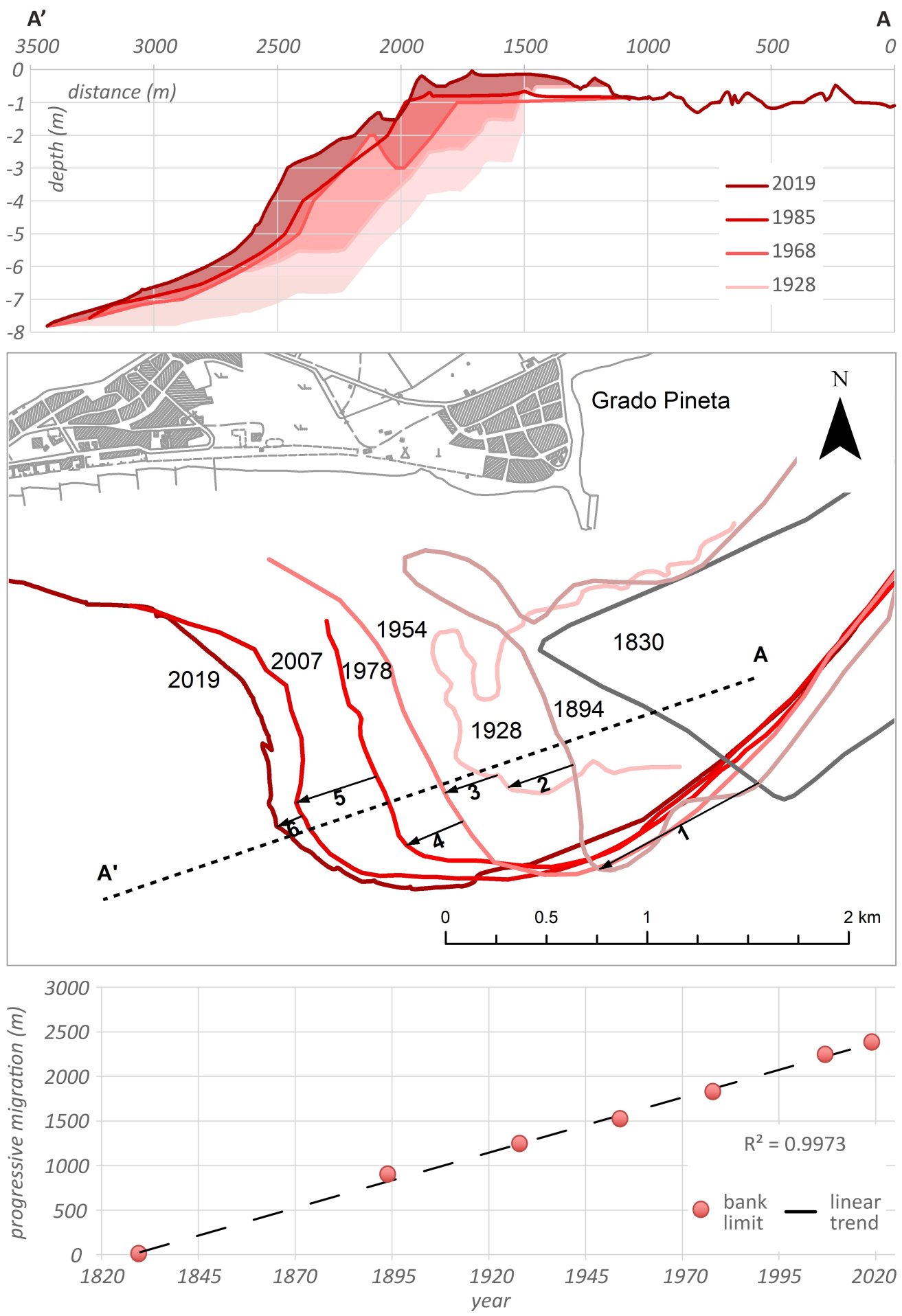

Figure 7. Detail of the bank migration analysed on the western front. 
Bathymetric data, on the other hand, have provided a cross-sectional view of the migration process (Figure 7), revealing a progradation involving the shoreface until the $-8 \mathrm{~m}$ depth. The upper part of the profile envelope depicts an aggradation process that leads to an elevation near the emersion at the top of the bank, as well as a recent proclivity to rollover.

\section{Discussion and Conclusions}

\subsection{The Sedimentary Surplus Anomaly and the Role of the Isonzo River}

The gathered and analysed data allowed for two major outcomes: on the one hand, the multidecadal analysis highlighted the evolution of the MMB and adjacent coasts over time, beginning with the earliest and most likely cartographic representations and progressing to modern high-resolution surveys; on the other hand, it was possible to describe the evolution of coastal landforms in relation to contemporary anthropogenic and tourist development.

Our work emphasises the importance of data obtained from historical maps, documents and orthophotos, in supporting proper coastal planning. The research has revealed the presence of a unique coastline system, a mosaic of natural and human-made landscapes, each with its own dynamism and physical characteristics. The MMB represents a morphological oddity if compared to the rest of the Adriatic: the presence of a vast system of submerged sandy shoals that created a wave dissipative domain has resulted in the beaches along the coast taking on the characteristics of "fetch limited beaches" (low wave energy) and having an anomalous appearance (very low elevation and slope, flat morphology, reduced carrying capacity).

Despite forcing factors such as the SLR and anthropogenic effect, the sandbank system has been documented in its overall shape since the early 1800s and has been preserved over time, conserving its overall structure, although with significant dynamism. The role of the Isonzo sedimentary depocenter in the constructive processes is supported by locally documented evolution: until 1950, the erosive phase of the barrier islands coincided with the shift of the mouth of the Isonzo to the eastern Gulf of Trieste, and since the mouth was brought back to Sdobba, the erosive effects on the coast appear to have been reduced.

The preservation of this system is in opposition to the prevalence of erosive behaviours on Italian beaches [69-71], erosion that appears to make exceptions where the coastline benefits from active riverine sedimentation or cannibalisation by deltaic dismantling [34,37,72-75]. The sedimentary budget will require future investigation but the geomorphological signals are unmistakably indicative of a notable sediment contribution by the Isonzo River, as follows:

- the current presence of vast sandy shoals at the mouth of the Isonzo;

- the wide area of sandy accumulation with emerging banks in front of the Grado beach.

- the ebb-tidal delta with a volume between 600,000 and 850,000 $\mathrm{m}^{3}$ at the Primero inlet which can be considered in equilibrium with its hydraulic cross-section and tidal prism [59]. The full development of the ebb-tidal delta, which can be temporally placed between 1949 [58] and 1995 [59], indicates a very rapid growth which can be attributed to a sediment flux from east to west greater than $60,000 \mathrm{~m}^{3} \mathrm{y}^{-1}$, calculated according to the Tidal Inlet Reservoir Model [76].

Furthermore, the reduction in sediment mining on the Isonzo riverbed, as well as an increase in the frequency of flood events can play in favour of a recent increase in the river sediment supply to the coast. Finally, artificial basins can change their function over time, and after a specific filling threshold has been reached, they can become "permeable" to solid transport. This is the case with the Crosis dam on the Torre torrent, a tributary of the Isonzo, which was rapidly filled thanks to a solid annual supply of 40,000-50,000 $\mathrm{m}^{3}$ [77] and no longer serves as a barrier to river sediment transport to the mouth. 


\subsection{The Conflict between Natural Dynamics and Poor Urban Planning}

The vast majority of the coastal territory between Grado and the Primero inlet was rapidly urbanised in two phases, the first towards the end of the 19th century and the second in the 1960s, to promote the growth of tourism. According to historical archives, new beaches were artificially formed using replenishment sands obtained from the neighbouring seabed [45]. The rest of the area, from Primero to Isonzo, was largely utilised for agricultural purposes. As a result of this rapid coastal development, a strong backshore defence policy ("keep the line") has been adopted, leading to a rigid system with no degrees of freedom in terms of possible beach migration to the hinterland. Despite the touristic development, many of the coastal area's natural elements have been preserved, leading to the implementation of a conservation program that includes the creation of the Natura 2000 protected areas. Consequently, the Grado coastline needs to be maintained for multipurpose use [78], balancing recreation and environmental conservation.

As a result of the historical analysis and more recent data collection, areas with varied morphosedimentary characteristics and with distinct tourist/recreational, ecological, and conservation values have been identified on a map (Figure 8).

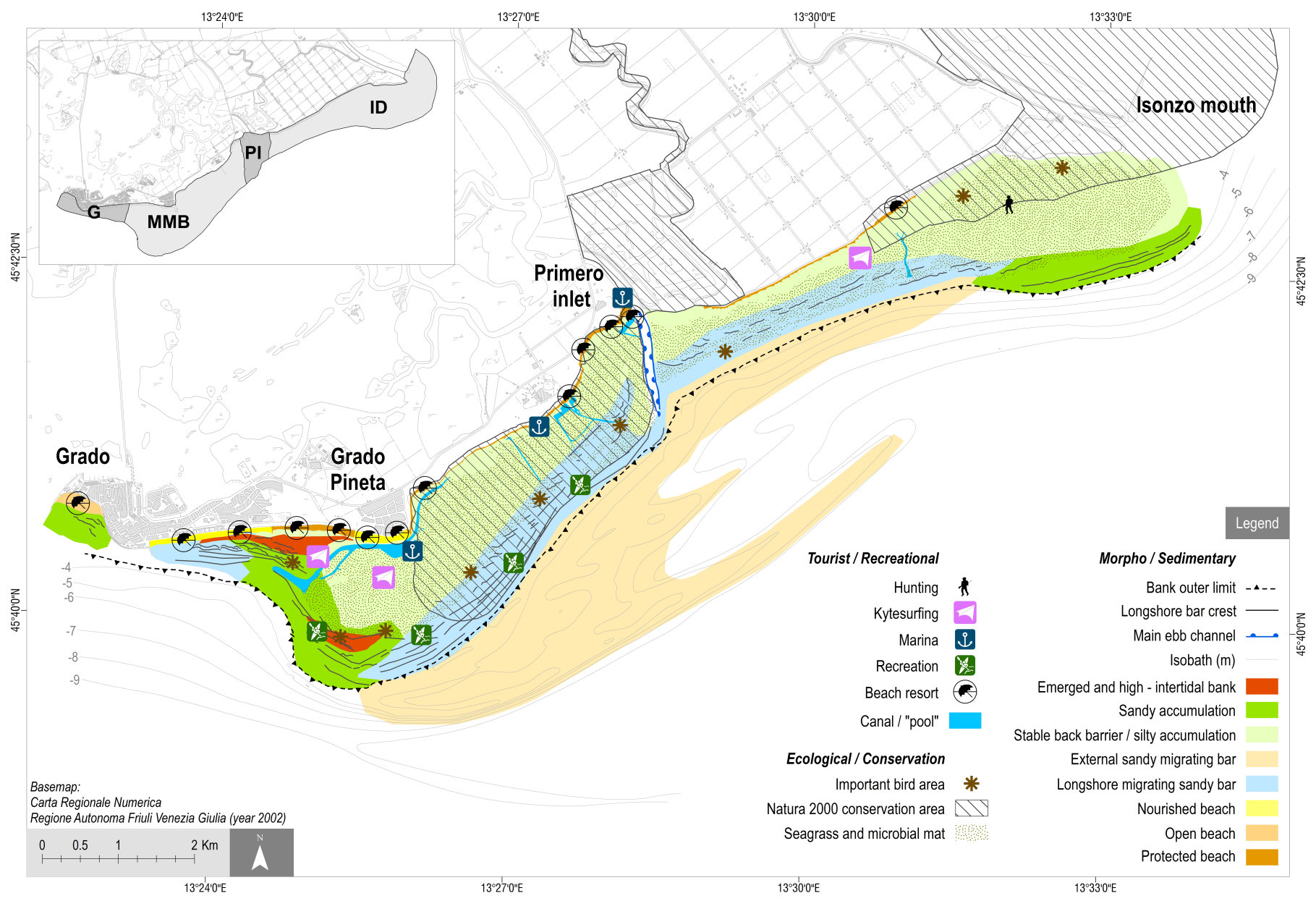

Figure 8. Zoning map with the different morphosedimentary areas and the most important tourist/recreational, ecological, and conservation values, relevant for multi-purpose coastal planning.

The zoning aims to synthesise natural dynamics, uses and conflicts and create a baseline for future management guidelines. The map emphasises how coastal areas have been developed without considering their inherent characteristics. In the absence of Integrated Coastal Zone Management or coordinated coastline management guidelines, the building of beach resorts and facilities occurred even in unsuitable areas located on fetch-limited beaches faced by very shallow waters and a silty seabed (backbarrier area). 
Despite the sheltered position during heavy storms and "acqua alta", some of these beaches are being eroded, and in the absence of post-storm natural constructive processes, they require periodic sand replenishment. Local coastal tourism is primarily focused on beaches that are managed as private properties under state concession and are fully equipped with numerous facilities (walkways, beach umbrellas, toilets, showers, and kiosks), leaving little space for free and natural areas. This model implies a lack of acceptance of the specific characteristics of the sites (particularly the backbarrier area) among stakeholders and fosters conflict. At the same time, a variety of touristic uses (small boat docks and kitesurfing, for example) can conflict with the need for nature conservation needs (silty seabed with seagrass meadows, tidal flats used as roosts by birds).

However, in certain locations, the large size and dynamism of natural landforms have grown prominent in relation to the needs of seaside tourism, raising serious concerns for the future of these areas. The westernmost part of the migrating bars, in particular, is viewed as a threat to touristic activities due to the ongoing rapid extension toward the west of the shallow water with silty deposition in the nearshore and the current infilling of the navigation canal. At the same time, longshore migrating sandy bars are being frequented by unorganized but intense tourist use (bathing, recreational fishing of edible bivalves and kitesurfing).

\subsection{Perspectives of Proper Coastal Management}

Our analysis, as well as the zoning scheme shown in Figure 8, can be used as a basis to guide future planning of the Grado coastal area, to reduce SLR impact and minimise or eliminate the major conflict that exists between coastal morphodynamics, tourist/recreational beach use, and conservation needs.

The backbarrier area and the longshore migrating sandbars have the natural potential to safeguard human settlements and infrastructures while also providing a variety of natural co-benefits such as habitat conservation, carbon sequestration, tourism opportunities, education, and research [79]. This area can be vulnerable to medium and long-term forcing (SLR), which can cause the sandbanks to rollover the stable silty backbarrier, a natural ramp for the accommodation of future transgressive bodies.

For this reason, the primary concerns are the preservation of the sediment source (the Isonzo River) and the natural ability of the longshore transport to distribute the sand along the littoral toward the west. Proper control of hydraulic interventions in the drainage basin and monitoring of the river's sediment supply, will be required. Simultaneously, hard defence structures should be avoided unless they are limited to reinforcing those already in place to defend the hinterland.

The presence of consistent sandy accumulation areas would favour soft shore protection solutions [80] that aim to manage sediments within the coastal system to balance deposition and erosion in adjacent cells [31-33,59]. Once sediment compatibility is established, overabundant sediments in accumulation areas can be managed as a temporary reservoir for beach re-nourishment. The use of small periodic, scheduled dredging and nourishment is preferable, with a source-to-sink approach that mimics the natural by-pass corridor between the barred shoreface updrift and downdrift to the Primero inlet. This approach is favoured here as deficit areas are of modest size and are mainly fetch-limited beaches, thus highly conservative.

As a final remark, correct monitoring of the morphodynamics of the coastal banks needs to be ensured to possibly re-direct the actions and planned management.

The abundance of sediments represents a source of great wealth as well as a concrete possibility to counter the SLR threat. While erosion and loss of sand are serious global issues for the tourism industry, the rapid morphological changes and the management of large quantities of moving sediments here represent a challenge as well as an opportunity.

Author Contributions: Conceptualization, A.B. (Annelore Bezzi), G.C. and G.F.; methodology, S.P. and D.M.; validation, A.B. (Annelore Bezzi) and G.F.; investigation, A.B. (Annelore Bezzi), S.F., G.C., S.P., D.M., A.B. (Antonio Bratus) and S.S.; resources, F.F.; writing-original draft preparation, A.B. 
(Annelore Bezzi), G.C. and G.F.; writing-review and editing, A.B. (Annelore Bezzi), G.C., D.M. and G.F.; supervision, G.F. and F.F.; project administration, A.B. (Antonio Bratus) and G.F.; funding acquisition, A.B. (Antonio Bratus) and G.F. All authors have read and agreed to the published version of the manuscript.

Funding: The research was founded by the 2014-2020 INTERREG VA Italy-Croatia CBC Programme, project ID 10043385 "Change We care". It also received financial support from the Regione Autonoma Friuli Venezia Giulia-Direzione centrale difesa dell'ambiente, energia e sviluppo sostenibile, through institutional partnership contracts "PR Mula di Muggia" and "PR Coste FVG".

Institutional Review Board Statement: Not applicable.

Informed Consent Statement: Not applicable.

Data Availability Statement: Not applicable.

Acknowledgments: This work is dedicated to our colleague and friend Ruggero Marocco, who sadly passed away. Ruggero was a great lover and connoisseur of the Grado territory, and he has always supported and assisted us in our coastal studies. He must be credited as the inspiration for this work.

Conflicts of Interest: The authors declare no conflict of interest.

\section{References}

1. Church, J.A.; Clark, P.U.; Cazenave, A.; Gregory, J.M.; Jevrejeva, S.; Levermann, A.; Merrifield, M.A.; Milne, G.A.; Nerem, R.S.; Nunn, P.D.; et al. Sea level change. In Climate Change 2013: The Physical Science Basis. Contribution of Working Group I to the Fifth Assessment Report of the Intergovernmental Panel on Climate Change; Stocker, T.F., Qin, D., Plattner, G.-K., Tignor, M., Allen, S.K., Boschung, J., Nauels, A., Xia, Y., Bex, V., Midgley, P.M., Eds.; Cambridge University Press: Cambridge, UK; New York, NY, USA, 2013. Available online: https://www.ipcc.ch/site/assets/uploads/2018/02/WG1AR5_Chapter13_FINAL.pdf (accessed on 26 October 2021).

2. Oppenheimer, M.; Glavovic, B.C.; Hinkel, J.; van de Wal, R.; Magnan, A.K.; Abd-Elgawad, A.; Cai, R.; Cifuentes-Jara, M.; DeConto, R.M.; Ghosh, T.; et al. Sea level rise and implications for low-lying islands, coasts and communities. IPCC Special Report on the Ocean and Cryosphere in a Changing Climate. Pörtner, H.-O., Roberts, D.C., Masson-Delmotte, V., Zhai, P., Tignor, M., Poloczanska, E., Mintenbeck, K., Alegría, A., Nicolai, M., Okem, A., et al., Eds.; 2019. Available online: https:/ / www.ipcc.ch/srocc/chapter/ chapter-4-sea-level-rise-and-implications-for-low-lying-islands-coasts-and-communities/ (accessed on 26 October 2021).

3. Anthony, E.J.; Marriner, N.; Morhange, C. Human influence and the changing geomorphology of Mediterranean deltas and coasts over the last 6000 years: From progradation to destruction phase? Earth-Sci. Rev. 2014, 139, 336-361. [CrossRef]

4. Besset, M.; Anthony, E.J.; Bouchette, F. Multi-decadal variations in delta shorelines and their relationship to river sediment supply: An assessment and review. Earth-Sci. Rev. 2019, 193, 199-219. [CrossRef]

5. McManus, J. Deltaic responses to changes in river regimes. Mar. Chem. 2002, 79, 155-170. [CrossRef]

6. Maselli, V.; Trincardi, F. Man made deltas. Sci. Rep. 2013, 3, 1926. [CrossRef]

7. Stutz, M.L.; Pilkey, O.H. The relative influence of humans on barrier islands: Humans versus geomorphology. In Humans as Geologic Agents; Ehlen, J., Haneberg, W.C., Larson, R.A., Eds.; Geological Society of America: Boulder, CO, USA, 2005 ; Volume 16. [CrossRef]

8. FitzGerald, D.M.; Fenster, M.S.; Argow, B.A.; Buynevich, I.V. Coastal impacts due to sea-level rise. Ann. Rev. Earth Plan. Sci. 2008, 36, 601-647. [CrossRef]

9. McBride, R.A.; Anderson, J.B.; Buynevich, I.V.; Cleary, W.; Fenster, M.S.; FitzGerald, D.M.; Harris, M.S.; Hein, C.J.; Klein, A.H.F.; Liu, B.; et al. 10.8 Morphodynamics of barrier systems: A synthesis. In Treatise on Geomorphology; Shroder, J.F., Ed.; Academic Press: New York, NY, USA, 2013; Volume 10, pp. 166-244. [CrossRef]

10. FitzGerald, D.M.; Hein, C.J.; Hughes, Z.; Kulp, M.; Georgiou, I.; Miner, M. Runaway barrier island transgression concept: Global case studies. In Barrier Dynamics and Response to Changing Climate; Moore, L.J., Murray, A.B., Eds.; Springer: Cham, Switzerland, 2018; pp. 3-56. [CrossRef]

11. De la Vega-Leinert, A.C.; Nichols, R.J. Potential implications of sea-level rise for Great Britain. J. Coast. Res. 2008, $24,342-357$. [CrossRef]

12. Martínez, M.L.; Hesp, P.A.; Gallego-Fernández, J.B. Coastal dunes: Human impact and need for restoration. In Restoration of Coastal Dunes; Martínez, M.L., Gallego-Fernández, J.B., Hesp, P.A., Eds.; Springer: Berlin/Heidelberg, Germany, 2013 ; pp. 1-14. [CrossRef]

13. Psuty, N.P.; Silveira, T.M. Global climate change: An opportunity for coastal dunes?? J. Coast. Conserv. 2010, 14, 153-160. [CrossRef]

14. Leatherman, S. Barrier dynamics and landward migration with Holocene sea-level rise. Nature 1983, 301, 415-417. [CrossRef]

15. Cooper, J.A.G.; Masselink, G.; Coco, G.; Short, A.D.; Castelle, B.; Rogers, K.; Anthony, E.; Green, A.N.; Kelley, J.T.; Pilkey, O.H.; et al. Sandy beaches can survive sea-level rise. Nat. Clim. Chang. 2020, 10, 993-995. [CrossRef] 
16. Cooper, J.A.G.; Green, A.N.; Loureiro, C. Geological constraints on mesoscale coastal barrier behavior. Glob. Planet. Chang. 2018, 168, 15-34. [CrossRef]

17. Zhang, K.; Douglas, B.; Leatherman, S. Do storms cause long-term beach erosion along the U.S. East Barrier Coast? J. Geol. 2002, 110, 493-502. [CrossRef]

18. McBride, R.A.; Byrnes, M.R.; Hiland, M.W. Geomorphic response-type model for barrier coastlines: A regional perspective. Mar Geol. 1995, 126, 143-159. [CrossRef]

19. Hapke, C.J.; Himmelstoss, E.A.; Kratzmann, M.G.; List, J.H.; Thieler, E.R. National Assessment of Shoreline Change: Historical Shoreline Change along the New England and Mid-Atlantic Coasts; Open-File Report 2010-1118; U.S. Geological Survey: Reston, VA, USA, 2011; 57p. Available online: https:/ / pubs.usgs.gov/of/2010/1118/ (accessed on 26 October 2021).

20. Morton, R.A. Historical changes in the Mississippi-Alabama barrier-island chain and the roles of extreme storms, sea level, and human activities. J. Coast. Res. 2008, 24, 1587-1600. [CrossRef]

21. Simeoni, U.; Fontolan, G.; Tessari, U.; Corbau, C. Domains of spit evolution in the Goro area, Po Delta, Italy. Geomorphology 2007, 86, 332-348. [CrossRef]

22. Kaminsky, G.M.; Ruggiero, P.; Buijsman, M.C.; McCandless, D.; Gelfenbaum, G. Historical evolution of the Columbia River littoral cell. Mar. Geol. 2010, 273, 96-126. [CrossRef]

23. Kombiadou, K.; Matias, A.; Ferreira, Ó.; Carrasco, A.R.; Costas, S.; Plomaritis, T. Impacts of human interventions on the evolution of the Ria Formosa barrier island system (S. Portugal). Geomorphology 2019, 343, 129-144. [CrossRef]

24. Ruggiero, P.; Kratzmann, M.G.; Himmelstoss, E.A.; Reid, D.; Allan, J.; Kaminsky, G. National Assessment of Shoreline Change: Historical Shoreline Change along the PACIFIC Northwest Coast; Open-File Report 2012-1007; U.S. Geological Survey: Reston, VA, USA, 2013; 62p.

25. Lebbe, L.; Van Meir, N.; Viaene, P. Potential implications of sea-level rise for Belgium. J. Coast. Res. 2008, 24, 358-366. [CrossRef]

26. Guillen, J.; Stive, M.J.F.; Capobianco, M. Shoreline evolution of the Holland coast on a decadal scale. Earth Surf. Process. Landf. 1999, 24, 517-536. [CrossRef]

27. Ruggiero, P.; Kaminsky, G.M.; Gelfenbaum, G. Linking proxy-based and datum-based shorelines on high-energy coastlines: Implications for shoreline change analyses. J. Coast. Res. 2003, 38, 57-82.

28. Rosati, J.D. Concepts in sediment budgets. J. Coast. Res. 2005, 21, 307-322. [CrossRef]

29. Hapke, C.J.; Lentz, E.E.; Gayes, P.T.; McCoy, C.A.; Hehre, R.; Schwab, W.C.; Williams, S.J. Review of sediment budget imbalances along Fire Island, New York: Can nearshore geologic framework and patterns of shoreline change explain the deficit? J. Coast. Res. 2010, 26, 510-522. [CrossRef]

30. Byrnes, M.R.; Rosati, J.D.; Griffee, S.F.; Berlinghoff, J.L. Historical sediment transport pathways and quantities for determining an operational sediment budget: Mississippi Sound Barrier Islands. J. Coast. Res. 2013, 63, 166-183. [CrossRef]

31. Fontolan, G.; Bezzi, A.; Martinucci, D.; Pillon, S.; Popesso, C.; Rizzetto, F. Sediment budget and management of the Veneto beaches, Italy: An application of the modified Littoral Cells Management System (SICELL). In Proceedings of the Coastal and Maritime Mediterranean Conference CM2, Ferrara, Italy, 25-27 November 2015; pp. 47-50.

32. Bonaldo, D.; Antonioli, F.; Archetti, R.; Bezzi, A.; Correggiari, A.; Davolio, S.; De Falco, G.; Fantini, M.; Fontolan, G.; Furlani, S.; et al. Integrating multidisciplinary instruments for assessing coastal vulnerability to erosion and sea level rise: Lessons and challenges from the Adriatic Sea, Italy. J. Coast. Conserv. 2019, 23, 19-37. [CrossRef]

33. Pranzini, E.; Cinelli, I.; Cipriani, L.E.; Anfuso, G. An integrated coastal sediment management plan: The example of the Tuscany region (Italy). J. Mar. Sci. Eng. 2020, 8, 33. [CrossRef]

34. Bezzi, A.; Pillon, S.; Popesso, C.; Casagrande, G.; Da Lio, C.; Martinucci, D.; Tosi, L.; Fontolan, G. From rapid coastal collapse to slow sedimentary recovery: The morphological ups and downs of the modern Po Delta. Estuar. Coast. Shelf Sci. 2021, 260, 107499. [CrossRef]

35. Rosati, J.D.; Stone, G.W. Geomorphologic evolution of barrier islands along the northern U.S. Gulf of Mexico and implications for engineering design in barrier restoration. J. Coast. Res. 2009, 251, 8-22. [CrossRef]

36. Acuña-Piedra, J.F.; Quesada-Román, A. Multidecadal biogeomorphic dynamics of a deltaic mangrove forest in Costa Rica. Ocean Coast. Manag. 2021, 211, 105770. [CrossRef]

37. Alberico, I.; Cavuoto, G.; Di Fiore, V.; Punzo, M.; Tarallo, D.; Pelosi, N.; Ferraro, L.; Marsella, E. Historical maps and satellite images as tools for shoreline variations and territorial changes assessment: The case study of Volturno Coastal Plain (Southern Italy). J. Coast. Conserv. 2018, 22, 919-937. [CrossRef]

38. Parsons, G.R.; Powell, M. Measuring the cost of beach retreat. Coast. Manag. 2001, 29, 91-103.

39. Pranzini, E.; Williams, A.T. (Eds.) Coastal Erosion and Protection in Europe; Routledge: London, UK; New York, NY, USA, 2013; 457p.

40. Alexandrakis, G.; Manasakis, C.; Kampanis, N.A. Valuating the effects of beach erosion to tourism revenue. A management perspective. Ocean Coast. Manag. 2015, 111, 1-11. [CrossRef]

41. Becken, S.; 2016 Climate Change Impacts on Coastal Tourism. CoastAdapt Impact Sheet 6, National Climate Change Adaptation Research Facility, Gold Coast. Available online: https://coastadapt.com.au/sites/default/files/factsheets/T312_7_Coastal_ Tourism.pdf (accessed on 26 October 2021).

42. Thinh, N.A.; Thanh, N.N.; Tuyen, L.T.; Hens, L. Tourism and beach erosion: Valuing the damage of beach erosion for tourism in the Hoi An World Heritage site, Vietnam. Environ. Dev. Sustain. 2019, 21, 2113-2124. [CrossRef] 
43. Arabadzhyan, A.; Figini, P.; García, C.; González, M.M.; Lam-González, Y.E.; Carmelo, J.L. Climate change, coastal tourism, and impact chains-A literature review. Curr. Issues Tour. 2021, 24, 2233-2268. [CrossRef]

44. Città di Grado-Presenza di Turisti. Available online: https://www.comunegrado.it/amministrazione-trasparente/507informazioni-ambientali/fattori-inquinanti/presenza-di-turisti (accessed on 26 October 2021).

45. De Grassi, P.; De Grassi, V. Memoria Sulle Variazioni Morfologiche dei Litorali Marini Della Laguna di Grado; A cura dell’Azienda Autonoma di Soggiorno-Grado: Grado, Italy, 1957; 54p. (In Italian)

46. Marocco, R. Lineamenti geomorfologici della costa e dei fondali del Golfo di Trieste e considerazioni sulla loro evoluzione tardo-quaternaria. Int. J. Speleol. 1989, 18, 87-110. (In Italian) [CrossRef]

47. Gatto, F.; Marocco, R. Caratteri morfologici ed antropici della Laguna di Grado (Alto Adriatico). Gortania Atti Mus. Friul. Stor. Nat. 1992, 14, 19-42. (In Italian)

48. Gordini, E.; Caressa, S.; Marocco, R. Nuova carta morfo-sedimentologica del Golfo di Trieste (Da Punta Tagliamento alla foce dell'Isonzo). Gortania Atti Mus. Friul. Stor. Nat. 2003, 25, 5-29. (In Italian)

49. Marocco, R.; Figus, B. Banchi sommersi della Mula di Muggia, Trezza Grande e Trezza Piccola. In Geositi del Friuli Venezia Giulia; Cucchi, F., Finocchiaro, F., Muscio, G., Eds.; Regione Autonoma Friuli Venezia Giulia, Tipografia Arti Grafiche Friulane: Udine, Italy, 2009; pp. 304-305. (In Italian)

50. Trobec, A.; Busetti, M.; Zgur, F.; Baradello, L.; Babich, A.; Cova, A.; Gordini, E.; Romeo, R.; Tomini, I.; Poglajen, S.; et al. Thickness of marine Holocene sediment in the Gulf of Trieste (Northern Adriatic Sea). Earth Syst. Sci. Data 2018, 10, 1077-1092. [CrossRef]

51. Regione Autonoma Friuli Venezia Giulia-Autorità di Sistema Portuale del Mare Adriatico Orientale. Piano Regolatore Portuale del Porto di Monfalcone, Variante Localizzata. Studio Meteomarino. Progettisti: Modimar, SJS Engineering, Archest. 2019. Available online: https://www.regione.fvg.it/rafvg/export/sites/default/RAFVG/ambiente-territorio/pianificazione-gestioneterritorio/FOGLIA9/allegati/Allegato_33_alla_Delibera_2066-2019.pdf (accessed on 26 October 2021).

52. INTERREG II. Progetto di Monitoraggio Dell'alto-Adriatico-Relazione Conclusiva, Luglio 1998-Giugno 2001; Direzione Regionale dell'Ambiente, Laboratorio di Biologia Marina: Trieste, Italy, 2001; 112p. (In Italian)

53. Regione Autonoma Friuli Venezia Giulia. Progetto CAMIS-Attività Coordinate Per la Gestione del Fiume Isonzo. Studio Morfologico del Fiume Isonzo. Relazione Generale. 2014. Available online: http:/ /www.camisproject.eu/modules/uploader/ uploads/system_menu/files_sys/studio-morfologico-art-prima-fase_copy1.pdf (accessed on 26 October 2021).

54. Regione Autonoma Friuli Venezia Giulia. Studio Sedimentologico e Marittimo Costiero dei Litorali del Friuli Venezia Giulia, Ipotesi di Intervento Per il Recupero Ambientale e la Valorizzazione Della Fascia Costiera; Brambati, A., Ed.; Regione Autonoma Friuli Venezia Giulia, Direzione Regionale dei Lavori Pubblici, Servizio dell'Idraulica: Trieste, Italy, 1985; 665p. (In Italian)

55. Siche, I.; Arnaud-Fassetta, G. Anthropogenic activities since the end of the Little Ice Age: A critical factor driving fluvial changes on the Isonzo River (Italy, Slovenia). Méditerranée 2014, 122, 183-199. [CrossRef]

56. Bezzi, A.; Pillon, S.; Martinucci, D.; Fontolan, G. Inventory and conservation assessment for the management of coastal dunes, Veneto coasts, Italy. J. Coast. Conserv. 2018, 22, 503-518. [CrossRef]

57. Petti, M.; Pascolo, S.; Bosa, S.; Bezzi, A.; Fontolan, G. Tidal flats morphodynamics: A new conceptual model to predict their evolution over a medium-long period. Water 2019, 11, 1176. [CrossRef]

58. Dorigo, L. La Laguna di Grado e le Sue Foci. Ricerche e Rilievi Idrografici; Magistrato Alle Acque-Ufficio Idrografico: Venezia, Italy, 1965; 231p. (In Italian)

59. Fontolan, G.; Pillon, S.; Delli Quadri, F.; Bezzi, A. Sediment storage at tidal inlets in northern Adriatic lagoons: Ebb-tidal delta morphodynamics, conservation and sand use strategies. Estuar. Coast. Shelf Sci. 2007, 75, 261-277. [CrossRef]

60. Interreg Italy-Croatia Change We Care. Report on Pilot Areas-Geomorphological Maps. Activity 3.2, Task 3.2.1, Version 1.0, Delivery Date 30 June 2020. Available online: https: / / www.italy-croatia.eu/documents/279156/0/3.2_RDV_D3.2.1_Pilot+areas+ geomorphologi-cal+map_rev.pdf/02261cd1-a210-280e-bba4-6a6aebec7f97?t=1614604207922) (accessed on 26 October 2021).

61. Arcanus Maps-Europe in the XIX Century. Available online: https://maps.arcanum.com/en/ (accessed on 26 October 2021).

62. Geoportale Nazionale-Servizio di Consultazione WMS. Available online: http:/ /www.pcn.minambiente.it/mattm/serviziowms / (accessed on 26 October 2021).

63. Falques, A.; Ribas, F.; Calvete, D. Rhythmic Shoreline Features. 2019. Available online: http://www.coastalwiki.org/wiki/ Rhythmic_shoreline_features\#cite_ref-G_17-0 (accessed on 26 October 2021).

64. Niedoroda, A.W.; Tanner, W.F. Preliminary study of transverse bars. Mar. Geol. 1970, 9, 41-62. [CrossRef]

65. Gelfenbaum, G.; Gregg, B. The morphology and migration of transverse bars off the west-central Florida coast. Mar. Geol. 2003, 200, 273-289. [CrossRef]

66. Ribas, F.; Kroon, A. Characteristics and dynamics of surfzone transverse finger bars. J. Geophys. Res. 2007, 112, F03028. [CrossRef]

67. Trincardi, F.; Correggiari, A.; Cattaneo, A.; Remia, A.; Taviani, M.; Angeletti, L.; Foglini, F.; Campiani, E. Carta Geologica dei Mari Italiani Alla Scala 1:250,000 Foglio NL 33-Venezia; ISPRA: Roma, Italy, 2011. (In Italian)

68. Desio, A. Le variazioni della foce del fiume Isonzo. Riv. Geogr. Ital. 1922, 10-11-12, 249-268. (In Italian)

69. GNRAC. Lo stato dei litorali italiani. Studi Costieri 2006, 10, 3-172. (In Italian)

70. Anfuso, G.; Martinez-del-Pozo, J.A.; Rangel-Buitrago, N. Morphological cells in the Ragusa littoral (Sicily, Italy). J. Coast. Conserv. 2013, 17, 369-377. [CrossRef]

71. Semeoshenkova, V.; Newton, A. Overview of erosion and beach quality issues in three Southern European countries: Portugal, Spain and Italy. Ocean Coast. Manag. 2015, 118 Pt A, 12-21. [CrossRef] 
72. Bellotti, P. Il modello morfo-sedimentario dei maggiori delta tirrenici italiani. Boll. Soc. Geol. Ital. 2000, 119, 777-792. (In Italian)

73. Pranzini, E. Updrift river mouth migration on cuspate deltas: Two examples from the coast of Tuscany (Italy). Geomorphology 2001, 38, 125-132. [CrossRef]

74. Alberico, I.; Amato, V.; Aucelli, P.P.C.; D'Argenio, B.; Di Paola, G.; Pappone, G. Historical shoreline evolution and recent shoreline trends of Sele plain coastline (southern Italy). The 1870-2009 time window. J. Coast. Res. 2011, 28, 1638-1647. [CrossRef]

75. Bezzi, A.; Casagrande, G.; Martinucci, D.; Pillon, S.; Del Grande, C.; Fontolan, G. Modern sedimentary facies in a progradational barrier-spit system: Goro lagoon, Po delta, Italy. Estuar. Coast. Shelf Sci. 2019, 227, 106323. [CrossRef]

76. Kraus, N.C. Reservoir Model for Calculating Natural Sand Bypassing and Change in Volume of Ebb-Tidal Shoals, Part I: Description; ERDC/CHL CHETN IV-39; US Army Corps of Engineers, Engineer Research and Development Center, Coastal and Hydraulics Laboratory: Vicksburg, MS, USA, 2002; 14p. Available online: https:/ /apps.dtic.mil/sti/pdfs / ADA588874.pdf (accessed on 26 October 2021).

77. Regione Autonoma Friuli Venezia Giulia. Indirizzi per l'Individuazione dei Corsi d'Acqua, o di Tratti dei Medesimi, nei Quali è Necessaria l'Esecuzione Degli Interventi di Manutenzione Degli Alvei che Prevedono l'Estrazione ed Asporto di Materiale Litoide. Aggiornamento. 2013. Available online: http://mtom.regione.fvg.it/storage/2013_676/Allegato\%201\%20alla\%20 Delibera\%20676-2013.pdf (accessed on 26 October 2021). (In Italian).

78. McLahlan, A.; Defeo, O.; Jaramillo, E.; Short, A.D. Sandy beach conservation and recreation: Guidelines for optimising management strategies for multi-purpose use. Ocean Coast. Manag. 2013, 71, 256-268. [CrossRef]

79. Sutton-Grier, A.E.; Wowk, K.; Bamford, H. Future of our coasts: The potential for natural and hybrid infrastructure to enhance the resilience of our coastal communities, economies and ecosystems. Environ. Sci. Policy 2015, 51, 137-148. [CrossRef]

80. Goudas, C.; Katsiaris, G.; May, V.; Karambas, T. (Eds.) Soft Shore Protection. An Environmental Innovation in Coastal Engineering; Springer: Dordrecht, The Netherlands, 2003; 398p. [CrossRef] 